\title{
Church of England Army Chaplains in the First World War: Goodbye to 'Goodbye to All That'
}

\author{
by MICHAEL SNAPE \\ University of Birmingham \\ E-mail:m.f.snape@bham.ac.uk
}

The British experience of the First World War has given rise to a host of myths and misconceptions in both the folklore and the historiography of the war. The most damaging of these for the Church of England has been that its army chaplains skulked in the rear while a generation of British men fought and died in the trenches of the Western Front. This article exposes the falsity of this myth, tracing its origins to the inter-war boom in 'war books' and its longevity among ecclesiastical historians in particular to the pacifist sensitivities and flawed historiography of the Ig6os and the I970s.

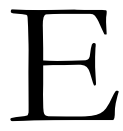
ven by the impressive standards of the wider historiography of Britain and the First World War, the subject of British army chaplains and their role in their country's bloodiest conflict is burdened with myth, misrepresentation and misunderstanding. The war that spawned in the national psyche the sense of a lost generation, an abiding anger at the supposed incompetence of chateau generals and an ultimate vision of the suffering and futility of war, ${ }^{1}$ has also inspired a distinctly negative perception of Anglican army chaplaincy. This perception holds that, while the Church of England acted as a cheerleader for the war, and was thus complicit in wholesale slaughter, the influence of its chaplains on those in uniform was woefully slight. While there were one or two notable exceptions to this rule (notably G. A. Studdert Kennedy, the eponymous 'Woodbine Willie', who has always been cast as an isolated and prophetic figure), the prevailing

IWM=Imperial War Museum, Department of Documents; RAChD=Royal Army Chaplains' Department Archive, Amport House; TLS=Times Literary Supplement

${ }^{1}$ For an incisive discussion of popular British perceptions of the First World War see A. Gregory, The last great war: British society and the First World War, Cambridge 2008, I-5, 294-5. 
wisdom holds that they were peripheral and ineffectual figures who were either sanctimonious misfits or worldly malingerers. In marked contrast, however, Roman Catholic chaplains are deemed to have set a very different example; spiritual, brave and devoted to a fault, only they were capable of inspiring much confidence among their coreligionists or among the sorely tried soldiers of the British army in general. Significantly, Presbyterian and Free Church chaplains, who comprised nearly a quarter of the Army Chaplains' Department by the end of the war, are conspicuously absent from the whole picture, a situation that would tend to imply their total irrelevance. These perceptions, like so much of the popular memory of the First World War, owe far more to literary contrivance than they do to historical fact.

It is worth making three general points about the post-war literature that has so distorted the subject. First, the I920s and early I930s saw a publishing boom in war-related literature. In I930 Cyril Falls, who had served on the Western Front and who went on to review much of this material for the Times Literary Supplement, ruefully remarked that 'The Great War has resulted in the spilling of floods of ink as well as of blood. '2 This literature comprised 'a great deal of poetry', a plethora of operational and unit histories, 'some drama' and a host of personal 'narratives, letters, and diaries' which, as Falls remarked, tended to become more critical of the war as the years passed. ${ }^{3}$ Inevitably, the tenth anniversary of the Armistice unleashed a new torrent of 'more personal reminiscences' and novels. Many of the former were, in fact, heavily fictionalised and Falls deemed them to be 'similar in type' to the latter, with the press and the general public knowing them collectively as 'war books'. ${ }^{4}$ Second, while thousands of veterans wrote novels and memoirs that remained unpublished, the main beneficiaries of the public appetite for 'war books', which seems to have reached its height between I928 and I93 ${ }^{\mathbf{5}}{ }^{\mathbf{}}$ were either established or aspiring writers prior to the war. As A. D. Harvey has warned, 'War books ... were not simply caused by the war ... the majority of the best-known works were by professed men of letters, some of whom had already made a name for themselves before i9i4.' As a result, 'the war ... became just one out of a list of possible topics once peacetime necessities reasserted themselves ... the books that were written and the moment at which their authors chose to write them related to the motivations and career strategies of a very disparate set of individuals' ${ }^{6}$ Third, and finally, while war books tended to embrace an anti-war position

${ }^{2}$ C. Falls, War books, 2nd edn, London i989, p. xiii.

${ }^{3}$ Ibid. p. xv.

4 Ibid. pp. xiv-xvi; H. Cecil, 'British war novelists', in H. Cecil and P. H. Liddle (eds), Facing Armageddon: the First World War experienced, London I996, 80I-16 at pp. 803-4.

5 D. Stevenson, I9I4-I9I8: the history of the First World War, London 2004, 577.

6 A. D. Harvey, A muse of fire: literature, art and war, London I998, I28-9. 
by the late ig2os (as their authors looked back at the war through the filter of a troubled decade and amidst a growing pacifist consensus) ${ }^{7}$ some, like Charles Edmonds's A subaltern's war (I929), continued to stress the more positive aspects of the war experience or, like Guy Chapman's A passionate prodigality (I933), conveyed a highly ambivalent message. ${ }^{8}$

According to Falls, most war books sought to capitalise on the phenomenal success of Erich Maria Remarque's All quiet on the Western Front (1929), a novel that had sold nearly four million copies worldwide by the end of I930 and which transformed Remarque into 'the world's most famous author'. Following his lead, their common characteristics included a fascination with sex, a carelessness with 'incidental details' and the close elision of dramatic 'scenes and events' beyond the point of absurdity. As Falls complained, 'Every sector becomes a bad one, every working-party is shot to pieces ... no one ever seems to have a rest ... Attacks succeed one another with lightning rapidity. The soldier is represented as a depressed and mournful spectre helplessly wandering about until death brought his miseries to an end. ${ }^{10}$ Nor was Falls alone in his scorn for the crude 'anti-war propaganda' peddled by most war books. To its many critics in Britain, the whole genre represented the 'lavatory school' of war-related literature. ${ }^{11}$ In I930 the novelist Ian Hay (another veteran of the Western Front) expressed the frustration of many when he declared that

We are being submerged by a flood of so-called war books which depict the men who fought for us in the late war for the most part as brutes and beasts, living like pigs, and dying like dogs. Some of these books are conceived in dirt and published for the profit dirt will bring. Nobody seems able to write on this subject without yielding to this tendency, and even if it is not the intention, it is so interpreted. ${ }^{12}$

Given the literary context in which the harshest and most influential criticism of Anglican chaplains was framed, the role and achievements of British army chaplains from I9I4 to IgI8 can now be summarised. In common with the rest of the British army, the Army Chaplains' Department experienced a huge wartime expansion; whereas there were only II commissioned chaplains representing three denominations in August I9I4, more than 5, ooo temporary commissions had been granted to clergymen of eleven denominations by November 1918. Of these, some 6o per cent were Anglican,

7 Stevenson, I9I4-I9I8, 579-80.

8 H. Cecil, The flower of battle: British fiction writers of the First World War, London I995, I-8; Gregory, The last great war, 272.

9 Falls, War books, p. xvi; M. Eksteins, 'Memory and the Great War', in H. Strachan (ed.),

The Oxford illustrated history of the First World War, Oxford I998, 305-17 at p. 313.

10 Falls, War books, pp. xvi-xvii. 11 Eksteins, 'Memory and the Great War', 315.

12 Press cuttings on Retreat, RAChD: Methodist Times, 6 Feb. I930. 
another 20 per cent were Roman Catholic, io per cent Presbyterian and, excepting a handful of Jews, the balance represented a mixture of English and Welsh Nonconformists. ${ }^{13}$ Despite their different ministerial priorities and their varied spheres of work (which could range from the front line in France to a hospital ship in the Arabian Sea), their prescribed duties were essentially the same. According to the bald requirements of King's Regulations, they were to conduct the army's compulsory religious services and bury its dead. On active service, and in accordance with the terms of the Geneva Convention of i864, chaplains were classed as hospital and ambulance personnel. In the context of the static warfare that set in on the Western Front from the autumn of IgI4, their status naturally precluded a free-ranging ministry to front-line trenches; indeed, a War Office ban was even imposed on this kind of approach. While Ben Tillett, the dockers' leader, used this ban to lambast the clergy at a TUC meeting in $1916,{ }^{14}$ too much should not be made of its application. Strongly protested against by senior Catholic and Anglican churchmen, the ban was widely flouted by chaplains themselves, most notably (but not exclusively) by Catholic chaplains attached to Irish infantry battalions. From early igı6, however, a new concept of the chaplain's role began to emerge on the Western Front, one that owed much to the personal convictions and professional instincts of Sir Douglas Haig and to preparations for that summer's Somme offensive. Having already been enlisted to continue the pre-war tradition of providing comforts and amenities for the troops, chaplains were called upon to preach the justice of the Allied cause and given much greater access to the front line; by the summer of 1916 they could be deployed wherever senior chaplains saw fit, even in offensive operations. Naturally, these developments resulted in a dramatic increase in

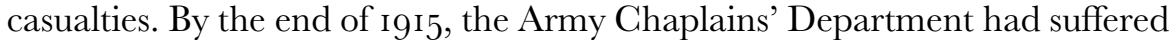
four fatalities due to enemy action; by the end of I9I8, this number had climbed to ioo. Of these, at least fifty-nine were Anglican while twenty-two were Roman Catholic. ${ }^{15}$ Members of the department also earned three Victoria Crosses (all Anglicans) and hundreds of lesser awards, the great majority being earned for assisting wounded men while under fire. Inevitably, and as in every other arm or service of Britain's improvised wartime army, not all chaplains rose to the challenges that confronted them and chaplains as a breed were not immune to criticism. Nevertheless, the army's verdict on their performance was overwhelmingly positive. In 1932 Sir J. E. Edmonds, the official historian of the war, wrote that 'Nothing can be truer than that the troops liked having chaplains with them ... they were

13 The Times, 28 June 1919,9 .

${ }^{14}$ R. Holmes, Tommy: the British soldier on the Western Front, I9I4-I9I8, London 2004, 508.

15 P. Howson, 'Deaths among army chaplains, I9I4-20', Fournal of the Society for Army Historical Research lxxxiii (2005), 63-77. 
a potent influence in the domain of morale, and often a useful link between the man in the ranks and his officer. ${ }^{, 16}$

Significantly, a corresponding sense of achievement was widely shared in the Church of England in the immediate aftermath of the war. In I920 Crockford's clerical directory stated that

The Temporary Chaplains serving in the Army numbered 3036, of whom II2 were killed or died on active service. A very remarkable list of decorations testifies to the work done by these men. They numbered 405 in all [including three VCs and 250 Military Crosses]. There were also some hundreds of [mentions in dispatches] of which there is no complete list. It is a war record of which the Church may be very proud. ${ }^{17}$

Fifty years later, and despite the currency of less favourable verdicts, F. R. Barry, who had served as a chaplain on the Western Front from I9I6 to I9I8, wrote that

The chaplains were allowed to move freely everywhere and when the units 'went up' we went with them. Several were awarded VCs, and a substantial number were killed in action ... We would give Holy Communion in the dugouts, minister to the wounded and dying, share, so far as we might, in what the troops endured ... We did what we could to serve them in Christ's name - and surely the distribution of cigarettes was a relevant form of the cup of cold water - and they understood that this was why we were doing it. They did not regard us just as welfare officers. In some dim way they discovered that they needed what the ministry of the Church sought to offer.

On this basis, Barry argued that the general conduct of Anglican chaplains had served to dispel a good deal of anticlerical prejudice: 'As a senior chaplain I got used to hearing, "Of course all padres are washouts, but we are very fortunate in ours, and I don't know how we could get on without him." When that had been said to one in every unit, one began to wonder just who were the washouts. ${ }^{\text {'18 }}$

An indication of their public standing in the immediate post-war years can be discerned in the plot and success of Ernest Raymond's novel Tell England, which was published in 1922. One of the first generation of war books, Tell England was written by a former Anglican chaplain and featured an Anglican padre as one of its central characters. The background of the novel was the Gallipoli campaign of $1915^{-1} 6$ and its principal theme the religious development of Rupert Ray and Edgar Doe, two young subalterns and alumni of 'a great public school'. The novel culminates in December I9I5

${ }^{16} \mathrm{~J}$. E. Edmonds, History of the Great War based on official documents by direction of the Historical Section of the Committee of Imperial Defence: military operations: France and Belgium IgI6 (I), Sir Douglas Haig's command to the Ist Fuly: Battle of the Somme, London i932, 135-8.

${ }_{17}$ Crockford's clerical directory (1920), p. v.

18 F. R. Barry, Period of my life, London i970, 6o-I. 
when Doe is mortally wounded in one of the last attacks before the British evacuation, leaving Ray to seek solace in the theology and friendship of 'Padre Monty', a 'big-hearted priest' who had captivated them with his fervent Anglo-Catholicism. Far from being a hapless and confused parson, Padre Monty is portrayed as 'spare, lean and vigorous', a veteran of the Western Front who had already been buried alive by a German shell; when Doe is fatally wounded, it is Monty who braves Turkish fire to bring him in from no-man's land. In addition, Monty is full of pastoral sympathy for his wider flock, touring hospital tents with his gramophone and admonishing his adoring neophytes that 'No one has a right to condemn them, who hasn't floundered in mud under shell-fire. ${ }^{19}$ The book was an instant bestseller and warmly received by the TLS; Cyril Falls ascribed its success to 'a combination of several qualities dear to the British middle-class reader - a lively story, not too obscure humour, sentiment laid on with a trowel but by a refined and gentlemanly hand, and a strong dash of religion ' ${ }^{20}$ Although Raymond resigned his orders in I923 due to personal doubts over miracles and the divine nature of Christ, ${ }^{21}$ Tell England (his first novel) established his reputation as a popular writer. One of the most successful of contemporary war novels, by 1939 it had sold 300,000 copies and such was its celebrity that a major screen adaptation was released in 193 ${ }^{2}{ }^{22}$ Four years in the making, this adaptation was filmed in Malta with the assistance of the armed services and met with wide critical acclaim. ${ }^{23}$

In contrast to the now familiar image of the skulking Anglican padre, criticism of Anglican chaplains was couched in very different terms in the decade after the war. Perhaps their earliest post-war critic was the travel writer Stephen Graham, who had served in the 2nd Scots Guards in I9I7-18. A Slavophil who combined an earnest admiration of the Russian peasantry with a deep regard for 'the simplicity, asceticism and mystical faith' of Russian Orthodoxy ${ }^{24}$ as an older conscript Graham took against the tough and unforgiving training regime he encountered at the Guards' depot. ${ }^{25}$ Nor did he find the religious customs and institutions of the British army much to his liking. In A private in the Guards, a memoir published less than a year after the Armistice, Graham declared that he 'would infinitely rather go to any civil church than to any military one' and condemned church parades as 'one of the unpleasant parts' of his 'enforced military life'. ${ }^{26}$ Furthermore,

19 E. Raymond, Tell England, New York 1922, passim.

20 TLS, 23 Feb. 1923, I23; Falls, War books, 293.

21 The Times, I6 May I974, 21 ; E. Raymond, The story of my days: an autobiography, I888-I922, London I968, I69-75.

${ }^{22}$ R. M. Bracco, Merchants of hope: British middlebrow writers and the First World War, 19I9-I939, Oxford I993, 29.

23 The Times, 5 Oct. 1927, I4; 3 Mar. I93I, I2; 23 Mar. I93I, Io.

24 Ibid. 20 Mar. I975, I7.

26 S. Graham, A private in the Guards, London I9I9, I03. 
having met 'ten or twelve chaplains' whilst serving with the elite Guards Division in France, Graham concluded that they were bellicose martinets ${ }^{27}$ and went on to claim that

The men, while they liked those who talked to them of home, were cold towards [chaplains] in the matter of religion. For the chaplains did not live the Christian life in any pictorial or dramatic way. The men no doubt thought that as servants of God they should be angels of mercy and light. They expected them to stand out in extraordinary contrast to the ugliness of war. ${ }^{28}$

While Graham reacted against many aspects of his life as a guardsman, a critical voice with a much wider perspective was that of Philip Gibbs, who had served as an official war correspondent for the Daily Telegraph and Daily Chronicle on the Western Front. As Britain's most famous war correspondent, Gibbs was an early and influential exponent of the post-war discourse of disillusionment, one that was engendered not so much by the war itself as by the many disappointing fruits of victory. ${ }^{29}$ In his Realities of war (1920), Gibbs assumed the mantle of 'the spokesman of youth that went to the war', a persona which some critics found to be rather implausible. ${ }^{30}$ Among many other things, Gibbs claimed that Anglican chaplains had been confronted with some formidable, even insuperable, theological problems:

God and Christianity raised perplexities in the minds of simple lads desiring life and not death. They could not reconcile the Christian precepts of the chaplain with the bayoneting of Germans and the shambles of the battle-fields. All this blood and mangled flesh in the fields of France and Flanders seemed to them - to many of them, I know - a certain proof that God did not exist, or if He did exist was not, as they were told, a God of Love but a monster glad of the agonies of men.

However, so Gibbs went on, such doubts were not widely expressed to Anglican army chaplains; they were more likely to be shared with some "human, comradely soul, some Catholic "padre" who devoted himself fearlessly to their bodily and spiritual needs ... or to some Presbyterian minister who brought them hot cocoa under shell-fire, with a cheery word or two' ${ }^{31}$ Consequently, the stalwart example of the Anglican chaplain was set at naught, for 'The devotion of military chaplains to the wounded, their valour, their decorations for gallantry under fire, their human comradeship, and spiritual sincerity, would not bridge the gulf in the minds of many soldiers, between a gospel of love and this argument by bayonet and bomb, gas-shell and high-velocity, blunderbuss, club and trench shovel. ${ }^{32}$ In contrast, as a devout Roman Catholic (and, indeed, the first journalist to gain an interview for publication with a reigning pope) Gibbs went to some

\footnotetext{
27 Ibid. 256-7. 28 Ibid. 257-8. $\quad 29$ Cecil, 'British war novelists', 820.

30 TLS, 4 Mar. I920, I5I. $\quad{ }^{31}$ P. Gibbs, Realities of war, London i920, I I7. ${ }^{32}$ Ibid. 364.
} 
lengths to stress not only the 'comradely' nature of the Catholic padre but also the greater efficacy of his spiritual work. ${ }^{33}$

Two years later, much of this verdict was echoed in Disenchantment by C. E. Montague, a chief leader writer and occasional editor of the Manchester Guardian, a paper that was owned and edited by his father-in-law, C. P. Scott. Although in his late forties Montague had volunteered for the army in December I9I4, enlisting in the 24th Royal Fusiliers, a battalion of Lord Kitchener's New Army. However, on arrival in France Montague saw only three weeks' service in the front line until failing health (an injured arm, trench fever and bronchitis) compelled his return to base and subsequently to England. However, by dint of Scott's efforts, he was plucked from an inglorious posting to Leith and commissioned as an intelligence officer in June 1916, returning to France and spending the rest of his war attached to the general headquarters of the British Expeditionary Force. Here he served as a press officer, working closely with 'the five or six war correspondents attached to the British forces', ${ }^{34}$ a highly select band that included Philip Gibbs. Montague was a passionate and radical Liberal; and his Disenchantment very much reflected his pre-war prejudices and opinions. Originally published as a number of newspaper and magazine articles, it extolled the voluntary spirit of the New Army, attacked various forms of disengagement from the war and, given the inadequacies of their social superiors, forcibly 'drew the conclusion that the working and middle classes were primarily responsible for victory in the absence of effective political and military leadership' ${ }^{35}$

Fiercely critical of the aristocratic world of General Headquarters, there was little in Montague's background or convictions to predispose him towards the Church of England; indeed, in a chapter entitled 'The sheep that were not fed' he was as critical of the army's Anglican chaplains as he was of its high command. Here, Montague repeated Graham's charge that the front-line Anglican chaplain had too readily embraced the business of war: 'He gladly frequented the least healthy parts of the line, and would frankly mourn the pedantry which denied him a service revolver. ${ }^{36} \mathrm{He}$ also echoed Gibbs's assertion that Anglican chaplains were poorly placed to deal with the fundamental religious problems of the war, blaming this on their poor professional training as well as on the practical demands of their wartime ministry:

What, indeed, could the average army chaplain have done, with his little budget of nice traits and limitations? How had we ever armed and equipped him? When you are given an infant earth to fashion out of a whirling ball of flaming metals and gases,

33 Ibid. 440.

34 The Times, 29 May i928, I7.

35 K. Grieves, 'C. E. Montague and the making of Disenchantment', War in History iv (I997), $35-59$ at p. 4I. 36 G. E. Montague, Disenchantment, London i922, 7I-2. 
then good humour, some taste for adventure, distinction at cricket, a jolly way with the men, and an imperfect digestion of thirty-nine partly masticated articles may not carry you far. ${ }^{37}$

If it had been unconvinced by Gibbs's presumptuousness, the TLS was extremely wary of Disenchantment and of its charges against chaplains in particular. As Orlo Williams put it,

In a telling chapter [Montague] deals with the Church as it appeared upon the field of battle-leaving it, we think, to be understood that his criticisms are mainly directed against the younger chaplains of the Church of England. His complaint is that 'virility' was pushed a little too far, and that a pathetic flock, with faint glimmerings of the food they wanted but could not ask for, were left hungering by their well-meaning shepherds. It is a chapter full of sympathy and understanding, and yet so sweeping that it does not wholly convince. ${ }^{38}$

Given their close relationship on the Western Front, ${ }^{39}$ their meeting of minds on the Treaty of Versailles ${ }^{\mathbf{4 0}}$ and their shared critique of Anglican chaplains, it is remarkable that Gibbs's and Montague's views on chaplains diverged in one major respect; whereas Gibbs praised Catholic chaplains to the skies, Montague was notably silent on the subject. However, this was once again a function of their personal backgrounds; while Gibbs was a star Catholic layman, Montague was the son of an Irish Catholic priest who had renounced his orders and settled with his wife in England. On marrying into the Scott family, the main religious influence upon him was Unitarian, a denomination that was distinguished by its historic anticlericalism and, during the war years, by its conspicuous eschewal of army chaplaincy.

If such criticism of Anglican chaplaincy was based as much on the pre-war convictions of its originators as it was on their post-war frustrations, it no doubt resonated with a perennial undercurrent of anticlericalism in British society, an animus that was largely directed against the clergy of the Church of England. As Hugh McLeod has shown, while not embraced by a major political movement in England in the pre-war era, anticlericalism was by no means a negligible force. Though widely diffused, anticlerical feeling 'remained significant in the private sphere' and had 'a significant influence both on the collective mentalities of certain groups and on the outlook of many individuals'. ${ }^{41}$ Such feeling was fed by a variety of personal grievances

37 Ibid. 82.

38 TLS, i6 Feb. i922, io6.

39 K. Grieves, "War correspondents and conducting officers on the Western Front from I9I5', in H. Cecil and P. H. Liddle (eds), Facing Armageddon: the First World War experienced, London I996, 719-35 at pp. 7I9, 723-4.

40 B. Bond, 'British anti-war writers and their critics', in H. Cecil and P. H. Liddle (eds), Facing Armageddon: the First World War experienced, London i996, 8I7-30 at pp. 820-I.

41 D. H. McLeod, 'Varieties of anticlericalism in later Victorian and Edwardian England', in N. Aston and M. Cragoe (eds), Anticlericalism in Britain, c. I5OO-I9I4, Stroud 200I, I98-220 at p. I99. 
and prejudices (such as resentment of the clergy's social position, of their role as moralising killjoys or of their supposed hostility to science and progress) and was most widely felt among Protestant, working-class males - a constituency that made up the greater part of the British army in the First World War. ${ }^{42}$ As Edward Madigan has rightly pointed out, the unflattering image of the civilian clergy that was taken with them into the army by Britain's citizen soldiers compelled Anglican chaplains 'to work hard to bridge the sheer cultural distance between themselves and the men they encountered' ${ }^{43}$ While the supreme example of this phenomenon was the ministry and persona of 'Woodbine Willie', the same imperative placed chaplains in an invidious situation, making them prone to make too much of an effort to embrace soldiering and the brutal business of war. As Montague sourly observed, in his dealings with soldiers 'Your virilist chaplain was apt to overdo, to their mind, his jolly implied disclaimers of any compromising connection with kingdoms not of this world. ${ }^{34}$ While the wartime conduct of Anglican chaplains left them open to sniping from writers such as Graham, Gibbs and Montague, it also stood to fuel wider anticlerical feeling in the longer term, especially as the Churches' role in the war came under closer critical scrutiny with the growth of an anti-war reaction in British society during the ig20s.

Whatever Anglican chaplains may have contributed to this abiding and amorphous miscellany of anticlerical grievance, titillating stories and scurrilous allegations concerning the clergy held a constant appeal for the general public - a fact that was underlined in the inter-war years by the longrunning saga of Harold Davidson, the notorious rector of Stiffkey. ${ }^{45}$ However, while there were lingering doubts as to Davidson's intentions and guilt in his dealings with numerous young women of doubtful reputation, there could be none about the work and career of a former chaplain named Robert Keable. A staunch Anglo-Catholic and the son of a Bedfordshire parson, Keable was ordained in I9I I and joined the Universities Mission to Central Africa in I912. After teaching at St Andrew's missionary college in the diocese of Zanzibar, Keable served as a missionary in Basutoland and, after approaching the bishop of Bloemfontein, he was duly commissioned as a chaplain to the South African Labour Corps in May $1917 .{ }^{46}$ On arrival in France, the duties of his flock usually kept Keable far from the front line and he essentially spent the rest of his war in and around the great base of Le Havre. ${ }^{47}$ Having already published City of the dawn, an account of his

42 Ibid. passim.

43 E. T. M. Madigan, 'Anglican army chaplains on the Western Front, I9I4-igi8', unpubl.

PhD diss. Trinity College, Dublin 2006, I52. $\quad 44$ Montague, Disenchantment, 72.

45 G. G. Brown, Religion and society in twentieth-century Britain, Harlow 2006, $130-5$.

46 The Times, 30 Dec. I927, I5; Crockford's (I9I3), 844; Cecil, Flower of battle, I63.

47 R. Keable, Standing by: war-time reflections in France and Flanders, London i9I9, 93. 
missionary work in Zanzibar, Keable published his wartime experiences in I9I9 under the laconic title of Standing by. Although not a member of the Army Chaplains' Department and ill-placed to speak on other spheres of the chaplains' work, from the standpoint of his posting to Le Havre Keable extolled the work of the YMCA, stating that 'I am certain half the chaplains in France might as well join in to the YMCA right away. It would be a strength to that organisation and an economy to the Army. ${ }^{, 48}$ On posing the question 'Why, then, are there chaplains in the British Army at all?' he replied by claiming that 'the real answer is that there always have been, and that there are people in England who would be annoyed if there were not'. ${ }^{49}$

Having already alleged the redundancy of the Army Chaplains' Department, Keable went a good deal further two years later when he published Simon called Peter. In no sense a ringing denunciation of the war, the significance of this novel lay in the fact that its hero was a young chaplain named Peter Graham and its subject his passionate affair with a free-spirited South African nurse named Julie Gamelyn. Besides his trysts with Gamelyn, Graham's moral crisis was also marked by his sexually charged friendship with a French prostitute and by 'orgies of drinks and ribaldry ... kissing waitresses [and] putting champagne corks down ladies' stockings as to the manner born' ${ }^{50}$ Significantly, while this was his first novel, as in his earlier work Keable brought a good deal of recent and relevant experience to Simon called Peter. In addition to its clerical hero and its setting against the backdrop of wartime Le Havre, Keable had become embroiled in an affair with a female driver while serving in France, forsaking his wife for his mistress in 1922. ${ }^{51}$ Whatever its inspiration, Simon called Peter was a staggering success in commercial terms; whereas sales of 2,000 copies were 'considered good for a first novel', ${ }^{52}$ Simon called Peter sold more than 300,00o in Keable's lifetime and funded his relocation to Tahiti, where he died from a kidney disorder in 1927 after converting to Roman Catholicism. ${ }^{53}$ As one admirer gushed, 'the book's triumphant sweep over two hemispheres' carried its author 'through half the countries of the world' and landed him 'in a paradise of flowers and sunshine in the South Seas ${ }^{, 54}$ furthermore, its success led to its adaptation as a London stage play and to a sequel, Recompense, in which Graham found his vocation as a Carthusian monk and Gamelyn as the 'matron of a maternity home' in which 'audacious sexual and eugenic theories' were put into practice. ${ }^{55}$

By the time that Recompense found its way to cinema screens in $1925,{ }^{56}$ the reputation of wartime Anglican chaplains had already taken a battering at

\footnotetext{
48 Ibid. 35, 39. 49 Ibid. 36.

50 R. Keable, Simon called Peter, London ig2 I, passim; TLS, 5 May i92 I, 290.

51 Cecil, Flower of battle, I67-9, I7I-4. $\quad 52$ Bracco, Merchants of hope, 28.

53 Cecil, Flower of battle, I54, I8I-3. $\quad 54$ The Times, 30 Dec. I927, I5.

55 TLS, 21 Feb. I924, Ii6. 56 The Times, i8 Aug. I925, Io.
} 
the hands of embittered journalists and scandalous clergymen. But worse was to come. Inspired by the contemporary passion for 'war books', Robert Graves published Goodbye to all that in November I929, an irony-laden memoir that his publisher, Jonathan Cape, fervently hoped would prove as saleable as All quiet on the Western Front. Although it never enjoyed anything like the spectacular success of Remarque's novel, it was nevertheless a solid enough triumph in commercial terms. Retailing at a hefty Ios. $6 d$., it sold 30,000 copies within a month of publication and provided Graves with the means with which to settle in Majorca.$^{57}$ Moreover, Goodbye to all that turned him into a literary celebrity and in time would ensure his place alongside Edmund Blunden, Wilfred Owen and Siegfried Sassoon at the heart of the popular canon of British soldier-writers of the First World War. Like all the literature so far examined, Goodbye to all that eludes simple categorisation as an anti-war text; although severely wounded in IgI6 and hospitalised with shell-shock the following year, Graves took enormous pride in having served as an officer in the 2nd Royal Welch Fusiliers and expressed some dismay 'at being acclaimed in headlines of daily papers as the author of a violent treatise against war' ${ }^{58}$ In fact, in Goodbye to all that Graves was actually bidding farewell to 'the stuffy conventions of pre-war society, wartime hysteria and personal problems at the time of writing ${ }^{59}$ However, if a catharsis for its author, Graves laid no claim to either altruism or historical rigour. As he wrote in But it still goes on, his self-styled 'appendix' to Goodbye to all that ${ }^{\mathbf{6 0}}$ the chief stimulus behind his magnum opus was the need to make 'a lump of money' quickly. Furthermore, in a letter to the Daily Mail, Graves admitted to having spared no effort to ensure the commercial success of his heavily fictionalised autobiography: 'I have more or less deliberately mixed in all the ingredients that I know are mixed into other popular books', his garnish including suicides, murders, ghosts, battles, love affairs, poets, Lawrence of Arabia and the prince of Wales. ${ }^{61}$ Significantly, Graves returned to this theme in 1957, writing in his prologue to the second edition of Goodbye to all that

I partly wrote, partly dictated, this book twenty-eight years ago during a complicated domestic crisis, and with very little time for revision. It was my bitter leave-taking of England where I had recently broken a good many conventions; quarrelled with, or been disowned by, most of my friends; been grilled by the police on a suspicion of attempted murder; and ceased to care what anyone thought of me.

57 TLS, 28 Nov. I929, 991 ; M. Seymour-Smith, Robert Graves: his life and work, London I982, I9I-4.

58 R. Graves, But it still goes on, London 1930, i6; B. Bond, The unquiet Western Front: Britain's role in literature and history, Cambridge 2002, 33-4. For a discussion of the textual complexities of Goodbye to all that see P. Fussell, The Great War and modern memory, Oxford 1975, $203-20$.

59 Bond, The unquiet Western Front, 33-4.

${ }^{60}$ Graves, But it still goes on, foreword.

${ }^{61}$ Ibid. ${ }^{3}{ }^{-1} 5$. 
Reading Goodbye to All That over again, for the first time since I929, I wonder how my publishers escaped a libel action. ${ }^{62}$

While he may have escaped litigation, Graves's cavalier and scattergun claims caused uproar in many circles. Among others, Goodbye to all that alienated his one-time friend Siegfried Sassoon, who accused Graves of numerous inaccuracies and of shamelessly exploiting their friendship. Similarly, J. G. Dunn, the medical officer of Graves's former battalion and the compiler of its acclaimed history The war the infantry knew, condemned Goodbye to all that as 'insincere, catchpenny \& deplorably wanting in taste' ${ }^{63}$ For his part, Cyril Falls also failed to see the joke, remarking that 'One might gather that thousands of men instead of a few hundred were executed, and that suicides were as a common as blackberries. [Graves] is, in short, another example of the "intellectual" whose intelligence with regard to the War penetrates a much shorter distance than that of the plain man. ${ }^{, 64}$ For reasons such as this, when answering his many critics in a letter to the TLS in June I930, in a further show of irony Graves argued that the factual inaccuracies that littered Goodbye to all that actually served to confirm its veracity, claiming that 'the memoirs of a man who went through some of the worst experiences of trench warfare are not truthful if they do not contain a high proportion of falsities. High-explosive barrages will make a temporary liar or visionary of anyone. ${ }^{\mathbf{6 5}}$

Despite this spirited defence, when writing to Sassoon in the vain hope of securing a loan in May i933, Graves admitted to being 'ashamed' of Goodbye to all that. ${ }^{\mathbf{6 6}}$ Furthermore, having prepared his second edition in the I950s, it was a seemingly contrite Graves who claimed that the text had now been properly revised and emended. ${ }^{67}$ However, there were some glaring factual errors that Graves did not correct. Thirty years earlier, and claiming to speak for the mass of his fellow soldiers, Graves had declared: 'For the regimental chaplains as a body we had no respect. If the regimental chaplains had shown one tenth the courage, endurance, and other human qualities that the regimental doctors showed, we agreed, the British Expeditionary Force might well have started a religious revival. But they had not. ${ }^{\mathbf{6 8}}$ Excepting Roman Catholic chaplains from this generalisation, Graves claimed that

The fact is that they were under orders not to get mixed up with the fighting, to stay behind with the transport and not to risk their lives. No soldier could have any

${ }^{62}$ Idem, Goodbye to all that, 2nd edn, London ig6o, prologue.

63 P. O'Prey (ed.), In broken images: selected letters of Robert Graves, I9I4-1946, London 1982, I97-208; J. C. Dunn, The war the infantry knew, 19I4-1919, London I994, 3I.

${ }^{64}$ Falls, War books, 202.

65 TLS, 26 June I930, 534; J. Winter, 'Ironies of war: intellectual styles and responses to the Great War in Britain and France', in C. Charle, J. Vincent and J. Winter (eds), Anglo-French attitudes: comparisons and transfers between English and French intellectuals since the eighteenth century, Manchester 2007, 284-98 at p. 288.

66 O'Prey, In broken images, 220.

${ }^{67}$ Graves, Goodbye to all that, 2nd edn, prologue. $\quad{ }^{68} \mathrm{Ibid}$. Ist edn, $242 ; 2$ nd edn, I58. 
respect for a chaplain who obeyed these orders, and yet there was not in our experience one chaplain in fifty who was not glad to obey them. Occasionally on a quiet day in a quiet sector the chaplain would make a daring afternoon visit to the support line and distribute a few cigarettes, and that was all ... Sometimes the colonel would summon him to come up with the rations and bury the day's dead, and he would arrive, speak his lines, and hastily retire. ${ }^{\mathbf{9}}$

In addition to impugning the courage of army chaplains, Graves also mocked their purity work among soldiers in France, claiming that diseased clerics were a conspicuous element among the patients of the venereal hospitals of the BEF and that the troops had taken 'a lewd delight in exaggerating the proportion of army chaplains to combatant officers treated there' ${ }^{\mathbf{7 0}}$

While these passages have certain echoes of Montague, Gibbs and Keable, the charge that Anglican chaplains skulked in the rear for the duration of the war (a charge that was made even more explicitly in the second edition) was entirely new in post-war writing and completely diverged from what had been alleged by Gibbs and Montague in their discourse of disenchantment. What, then, had led Graves to make and maintain such claims? Setting aside the remote possibility of a genuine and sustained lapse of memory, the war had profoundly changed his religious outlook, marking his transition from an evangelical Anglican to 'a complete agnostic', and his marriage to Nancy Nicholson, a staunch feminist and convinced atheist. ${ }^{71}$ By the late ig2os Graves's anticlericalism was emphatic, even vicious. In But it still goes on, he mused malevolently: 'What makes the most horrible collective monster? Organised motherhood or organised clergy? Motherhood the most terrifying, clergy the most provocative.' He then went on to relate an anecdote concerning his eldest son who, when three years old, called upon his driver to plough through a crowd of clergymen who blocked their way during an Anglican conference in Oxford. ${ }^{72}$ In sum, it seems that Graves's strong animus against the Church of England and his desperate desire to make a splash with Goodbye to all that led him to revive memories of the ban on chaplains visiting front-line trenches, a ban to which he lent a new, ironic and distorting twist. Whatever the degree of calculation involved, the resurrection of this memory probably resonated with a new groundswell of anticlerical feeling in English society, a groundswell stirred by the confusion and timidity of the Churches during the coal dispute and General Strike of i926, by antitithe agitation in southern England in the early I930s, by widespread resentment at the treatment of Harold Davidson and by a burgeoning popular rejection of the war. ${ }^{73}$

69 Ibid. Ist edn, 242; 2nd edn, 158.

${ }^{71}$ Ibid. 2nd edn, 45, 207, 221, 223.

73 A. Hastings, A history of English Christianity, I920-199o, London I991, I86-92; H. Barron, " "T'is very embarrassing, say what you like, to be a good vicar in a valley on strike": the Church of England and its relationship with the Durham miners at the time of the 1926 
Significantly, Graves was in a position to corroborate and amplify his attack on the Church of England through a literary protégé, Frank Richards, a former miner and regular soldier of his old battalion. In I933, and with Graves's help, Richards published Old soldiers never die, another commercially successful memoir that betrayed much Gravesian influence in terms of its style and content (in fact, in a letter written to Basil Liddell Hart two years later, Graves confided that he had been 'privately, godfather to that book'). ${ }^{74}$ Greatly benefiting from his literary assistance, Richards happily described Graves as a brave and 'highly respected' officer' ${ }^{75}$ and cheerfully endorsed his patron's portrayals of the Anglican clergy and of Anglican chaplains in particular. Having harboured a deep contempt for organised religion since his boyhood in the Monmouthshire mining village of Blaina, Richards was keen to enlarge upon the theme of lecherous padres, claiming that a fellow soldier had lambasted one wayward 'parson' on account of his lewd designs on a French girl on whom he had been billeted. ${ }^{76}$ Similarly, Richards echoed Graves's assertion that 'Parsons always stayed with the transport when we were in the line', adding that one clerical sot only ventured into the trenches in order to drink company officers out of their whisky. ${ }^{77}$ Appealing for good measure to the pacifist mood of the day, Richards also castigated the clergy of Britain and Germany for their conflicting appeals to the Almighty and for their refusal to carry arms: 'The Clergy on both sides were a funny crowd: they prayed for victory and thundered from the pulpits for the enemy to be smitten hip and thigh, but did not believe in doing any of the smiting themselves. ${ }^{78}$ However, and despite his insistence on clerical misconduct of various kinds, it was doubly ironic that Richards blithely went on to recount several examples of chaplains being present with their troops in the front line ${ }^{79}$ Given its tenor and internal tensions, Cyril Falls remarked upon the 'somewhat elastic conscience' that lay behind the memoir $;{ }^{80}$ Graves, however, was at hand to enter a familiar caveat in the TLS, pleading that their secret co-production 'should not be read as a record of individual experience in the Great War ... but as an expression of that regimental spirit that has persisted in the ranks of the Royal Welch Fusiliers - a typical Line regiment - ever since it was formed'. ${ }^{81}$ Whatever its factual problems, Old soldiers never die was yet another success in commercial terms. Within three years, I0,00o copies had been sold in Great Britain alone at $7 s .6 d$. each. Graves took a third of the royalties. ${ }^{82}$

lockout', Twentieth Century British History xvii (2006), 350-72; S. Mews, 'The Churches' in M. Morris (ed.), The General Strike, London 1976, 318-37; E. R. Norman, Church and society in England, I770-I990, Oxford 1976, 346.

75 F. Richards, Old soldiers never die, London I983, Iog.

77 Ibid. $85^{-6 .}$

80 TLS, 3I Aug. 1933, 57I.

${ }^{78}$ Ibid. 3 or.

81 TLS, I4 Sept. I933, 6i I.

${ }^{82}$ Seymour-Smith, Robert Graves, 223, 253; TLS, 31 Aug. I933, 57 I. 
It was an indication of the currency which Graves's charges quickly attained that they were directly addressed in Guy Chapman's A passionate prodigality, a more nuanced memoir that enjoyed modest but significant success on its publication in I933 (copies sold out in a day but further editions were prevented by production problems including the death of Chapman's publisher). ${ }^{83}$ Significantly, while Chapman qualified Graves's claims regarding Anglican chaplains, he took up the refrain of extolling Roman Catholic chaplains at their expense. Recalling the visits of Fr James Leeson to the trenches of the isth Royal Fusiliers, Chapman pronounced that:

These Catholic priests impressed one. Leeson never dropped a word of religion in my hearing; but one felt a serenity and certitude streaming from him such as was not possessed by our bluff Anglicans. Already there was a growing dislike of these latter. They had nothing to offer but the consolation the next man could give you, and a less fortifying one. The Church of Rome sent a man into action mentally and spiritually cleaned. The Church of England could only offer you a cigarette. The Church of Rome, experienced in propaganda, sent its priests into the line. The Church of England forbade theirs forward of Brigade Headquarters, and though many, realising the fatal blunder of such an order, came just the same, the publication of that injunction had its effect. ${ }^{84}$

While Graves had sown the seeds of trouble for the future, his calumnies were temporarily eclipsed by the lengthiest, most lurid and most controversial attack on Anglican chaplains which came in the form of a novel rather than a memoir. Published within weeks of Goodbye to all that, Retreat: a story of IIIO took as its subject the moral, physical and spiritual collapse of an Anglican artillery chaplain against the background of the German spring offensive of Igr8. Written by Charles Benstead, who had served with the Royal Garrison Artillery on the Western Front and who was now a lieutenant-commander in the Royal Navy, at $7 s .6 d$. Retreat was not only cheaper than Goodbye to all that but its potential readership was greatly enlarged by its serialisation in the Evening Standard, which sold at only a penny. ${ }^{85}$ Although dedicated 'In Respect and Affection' to a naval chaplain (a barbed tribute that in itself implied a far more positive experience of chaplains in the senior service) Benstead's portrayal of his central character, a High and dry army chaplain by the name of Elliot Warne, was utterly damning. Painfully inept and wholly incapable of adjusting to his new and 'bewildering life' ${ }^{86}$ Warne's military career concludes with his death from influenza in June 1918, his inglorious exit being preceded by the loss of his faith and his sanity. ${ }^{87}$ In addition to the caricature of Warne, the novel was

${ }^{83}$ B. Bond, Survivors of a kind: memoirs of the Western Front, London 2008, 28.

${ }^{84}$ G. Chapman, A passionate prodigality: fragments of autobiography, London I985, II7.

${ }^{85}$ Letters about RETREAT by Benstead I929, RAChD: A.C.E. Jarvis, undated memorandum.

${ }^{86}$ C. Benstead, Retreat: a story of I9I8, London I930, 8.

${ }^{87}$ Ibid. $3{ }^{10-}$ - 8 . 
peppered with profanities, it featured the consecration (and subsequent desecration) of a ration biscuit, a drink-sodden officers' mess and an unequivocal statement that 'No parson is really necessary out here, some are merely less unnecessary than others. ${ }^{98}$ In common with other critics, Cyril Falls felt that the character of Warne had been greatly overdrawn, complaining in his review for the TLS that his 'sheer stupidity is exaggerated. It is hard to imagine that he could have been a success in the sleepiest and least exacting of parishes ${ }^{99}$ Elsewhere, in his later survey of 'war books', Falls reflected that

Put a narrow-minded, very nervous, unhumorous chaplain, fresh from a sleepy country parish at home, into the mess of a heavy artillery brigade five hours before the launching of the great German offensive of the 2ist March I9I8, and it may be anticipated that he will know troubled and unhappy days. A tragedy so complete as that of the Reverend Elliot Warne is, however, not to be anticipated, and we are not sure that the author has not overstrained probabilities in his depiction of Warne's terrible end. ${ }^{90}$

What did the Church of England do to challenge these repeated slurs on the record of its wartime chaplains? Unfortunately, the truth appears to be that it did very little. Significantly, the Padres' Fellowship, which had originated as an association of former Anglican chaplains in the summer of I9I8, was to all intents and purposes irrelevant to the debate. Having reconstituted itself in I9I9, it became an ecumenical and reformist pressure group that was chiefly preoccupied with 'the question of Reunion'; indeed, it was precisely in order to avoid becoming a clerical old comrades' association that in I92 I it diluted itself still further by opening its membership to all who were in sympathy with its aims. ${ }^{91}$ An effective defence was further hampered by the lack of a contextual history of their wartime role. Despite the multitude of unit and formation histories published in the Ig2os (some of which were even written by former chaplains $)^{\mathbf{9 2}}$ the Army Chaplains' Department never produced a history of its own involvement in the war. Indeed, in I922 a serving chaplain deplored the fact that 'Other agencies which were at work among the troops did not hide their light under a bushel, but, so far, no one has tried to enlighten the general public as to how our Department did its work, the main testimony to their efficiency being the casualty lists and the award of V.C.s. ${ }^{, 93}$

${ }^{88}$ Ibid. passim. $\quad{ }^{89}$ TLS, 6 Feb. I930, 96. $\quad{ }^{90}$ Falls, War books, 265.

91 The Times, 7 Dec. I918, 5; E. C. Crosse, IWM, 80/22/I; B. K. Cunningham, 'The Padres' Fellowship', RAChD Quarterly fournal i (1922), I5-17.

${ }_{92}$ Notable examples included E. C. Crosse, The defeat of Austria as seen by the 7 th Division, London I919; P. Middleton Brumwell, History of the I2th (Eastern) Division in the Great War, I9I4-I9I8, London I923; and J. O. Coop, The story of the 55th (West Lancashire) Division, Liverpool I9I9.

${ }_{93}$ H. G. Meeke, 'Review of the general history of the department', RAChD Quarterly fournal i (I922), II-I5 at p. I4. 
More striking still, there was even a dearth of denominational histories of chaplaincy work. Remarkably, such projects were initiated but none were ever completed. In I9I9 B. K. Cunningham, the principal of the chaplains' school of instruction at St Omer, planned a wide-ranging volume that was to be entitled The work of the Church of England chaplains in the B.E.F. Consisting of eight chapters dealing with different aspects of their ministry, it was to be published by the SPCK and E. C. Crosse, formerly the senior Anglican chaplain of the 7 th Division, contributed a chapter entitled 'With an infantry brigade at the Front'. However, the project was never finished, its surviving remnant being Crosse's chapter which is now kept among his papers at the Imperial War Museum. Significantly, Crosse always lamented the failure of the wider project, remarking that 'War histories of almost all sorts have appeared, but in most of these there is very little reference to Chaplains, and, even where there is, the writers often generalise from their experience of a very few. ${ }^{, 94}$ In a similar vein, and partly prompted by a 'perfectly useless' American precedent, ${ }^{95}$ Bernard Rawlinson, who had served as the senior Roman Catholic chaplain on the Western Front for the latter half of the war, began to collect materials for a Roman Catholic history in i925. Avowedly propagandist in its intent, Rawlinson approached his former subordinates explaining that 'What I particularly want is matter which shows the difference of the R.C. Chaplain from all other denominations, in his dealings with the men through the Sacraments or otherwise, and stories of experiences in your own sphere, that would be of general interest. ${ }^{96}$ Although this project also came to naught, the absence of an official record was far less damaging to the reputation of Roman Catholic chaplains, who were in the happy position of having much of their inter-war propaganda written for them.

In the absence of any broader, contextual record of the work of the Army Chaplains' Department or of its principal components, it was perhaps inevitable that certain individuals should acquire an undue significance. With the return of the bishop of Khartoum, L. H. Gwynne, to the Sudan shortly after the war, the Anglican veterans of the Chaplains' Department lost their figurehead and their natural post-war leader. As deputy chaplain-general on the Western Front from July 1915, Gwynne had directed the largest concentration of Anglican chaplains in any theatre of war and had served with great distinction. A former brigade chaplain and a skilled and pragmatic manager, he had imposed order and purpose on a disparate and fractious body of clergy while earning the widespread admiration and affection of his subordinates. While he held in check party disputes and the zeal of noisy

${ }^{94}$ E. C. Crosse, IWM.

95 "“War history" material', 1925, Rawlinson papers, Downside Abbey; Ordinariate Army and Navy Chaplains, United States Catholic chaplains in the world war, New York I924, passim.

96 "“War history" material', I925, Rawlinson papers. 
reformists such as Neville Talbot and Tom Pym, in military terms he had gained the trust and admiration of the army's high command, General Herbert Plumer crediting him with having done more than anyone else to ensure eventual victory ${ }^{97}$ However, and probably because of Gwynne's longstanding antipathy towards Lloyd George and his kinship with Howell Gwynne of the Morning Post, one of the prime minister's bitterest critics in the wartime press, there was no prospect of an English see for the bishop of Khartoum. ${ }^{98}$ Given Gwynne's departure and his personal silence on the war, the stage was thrown open to some of his more charismatic protégés. While 'Tubby' Clayton gained international celebrity as the founder and promoter of the Toc $\mathrm{H}$ movement, a Christian ex-servicemen's organisation which by 1930 had become 'the biggest and most wholesome men's Society in the Empire' ${ }^{99}$ in domestic terms even he was eclipsed by G. A. Studdert Kennedy, the celebrated 'Woodbine Willie'. A consummate showman, preacher and wordsmith, Studdert Kennedy had been used in a number of special roles by Bishop Gwynne; after making his reputation while serving as a base chaplain at Rouen, he was chosen to preach the National Mission of Repentance and Hope on the Western Front and was thereafter posted as a star turn to a succession of divisions and training establishments. ${ }^{100}$ In January I9I8 Gwynne had even sponsored the publication of Studdert Kennedy's Rough rhymes of a padre, ${ }^{\mathbf{1 0 1}}$ a volume that established his reputation as a vernacular poet and which underlined his exceptional talents as a communicator.

While Studdert Kennedy remained convinced of the necessity of an allied victory (if only because the allies were ultimately fighting 'in order to end all war' $)^{102}$ he was by nature, and as one senior chaplain wrote, 'an extremely highly strung person [who] could never have stood long uninterrupted periods in the front line' ${ }^{103}$ Nevertheless, he was typically forthright in his views as to the nature of war, stating in I9I8 that 'War is only glorious when you buy it in the Daily Mail' and declaring that 'War is just sin in a million forms, in a million of God's gifts misused. ${ }^{104}$ With the coming of victory and the advent of a troubled peace, Studdert Kennedy's feelings increasingly found expression in an uninhibited rhetoric of disenchantment.

${ }^{97}$ H. C. Jackson, Pastor on the Nile: being some account of the life and letters of Llewellyn H. Greynne, London i96o, I69.

98 M. Snape, The Royal Army Chaplains' Department, I796-1953: clergy under fire, Woodbridge 2008, $25^{6-7}$.

${ }^{99}$ Idem, God and the British soldier: religion and the British army in the First and Second World Wars, London 2005, 219.

100 D. F. Carey, 'Studdert Kennedy: war padre', in J. K. Mozley (ed.), G. A. Studdert Kennedy by his friends, London I929, II5-6I at p. I25.

101 G. A. Studdert Kennedy, The hardest part, London i918, 6.

${ }^{103}$ Carey, 'Studdert Kennedy: war padre', I24-5.

104 Studdert Kennedy, The hardest part, I1 $3-16$. 
In Lies!, first published only a year after the Armistice and reprinted many times in the next twenty years, he stated his case 'in a nutshell': 'Does God will War? Is it part of His mysterious plan...? I answer: "If God wills War, then I am morally mad, and I don't know good from evil." War is the most obviously wicked thing I know. If God wills War then I am not an atheist, I am an anti-theist. I am against God. I hate Him. ${ }^{105}$ This loathing of war was to become a major theme in his preaching as Messenger for the Industrial Christian Fellowship. According to P. T. R. Kirk, another veteran of the Army Chaplains' Department,

The horror of war, which he learned as he lived with the troops, grew, not diminished, as each year carried him farther and farther from those fateful years ... It was a great thing to have the holder of a Military Cross, whose patriotism was unquestionable, who had been over and over again in the heat of battle, denouncing war and the mind that leads to war, in the terms he used. ${ }^{106}$

However, Studdert Kennedy was also prone to vent his feelings in very public bouts of self-recrimination. ${ }^{107} \mathrm{In}$ a speech at Westminster Hall on Armistice Day I92 I (a year in which the unemployed comprised I I per cent of the British workforce) ${ }^{\mathbf{1 0 8}}$ he declared that 'I was mad-crazy. We got decorated for doing things that we did when we were mad'; he also caused a furore by insisting that the war had been 'futile'. ${ }^{109}$ Perhaps most poignantly, in his rueful poem 'Woodbine Willie' (first published in 1927) he wrote:

Their name! Let me hear it - the symbol

Of unpaid - unpayable debt,

For the men to whom I owed God's Peace, I put off with a cigarette. ${ }^{110}$

Due to his quasi-prophetic status, Studdert Kennedy's declarations of regret stood as a powerful reproach to his fellow chaplains, much as his colourful behaviour and his 'constant use of forcible and startling expressions' 111 had served to rebuke the stuffy professional mores of the Anglican clergy. However, with the growth of a popular reaction against the war in British society during the I920s, by the time of his death in I929 Studdert Kennedy's opinions were much more widely shared among his former colleagues. While Neville Talbot had been an outspoken advocate of reconciliation with

105 Idem, Lies!, London i937, I3.

106 P. T. R. Kirk, 'Studdert Kennedy: ICF crusader', in Mozley, Studdert Kennedy, r65-91 at pp. I67-7I.

107 G. A. Studdert-Kennedy, Dog-collar democracy: the Industrial Christian Felloweship, 1919-1929, Basingstoke $1982,5^{8}$.

108 D. Todman, The Great War: myth and memory, London 2005, I30.

109 Studdert-Kennedy, Dog-collar democracy, 6r; Todman, The Great War, I32.

110 G. A. Studdert Kennedy, The unutterable beauty: the collected poetry of G. A. Studdert Kennedy, London I927, I.

111 Carey, 'Studdert Kennedy', I59. 
Germany from as early as $1919,{ }^{112}$ with the passage of a decade or so it appeared to F. R. Barry at least that most of his fellow veterans of the Army Chaplains' Department had developed pacifist leanings, and it was certainly symbolic that a former Anglican chaplain, Charles Raven, should have become chairman of the Fellowship of Reconciliation in $1932 .{ }^{113}$ Furthermore, it was key to Dick Sheppard's credibility as the originator of the Peace Pledge Union that he was able to lay claim to some chaplaincy experience, a past that he greatly embellished by claiming to have served for several years in the Army Chaplains' Department, rather than for a few weeks in I9I4 with the Australian Volunteer Hospital. ${ }^{114}$ Significantly, at least some of Sheppard's inter-war admirers were under the fantastic misapprehension that he 'had served as a chaplain in the war and got an MC for rescuing wounded men under fire' $\mathbf{1 1 5}$

In such a climate, and at a time when their reputation was most under attack, it was difficult for other former chaplains to defend their wartime record. In February I930, in the wake of the Kellogg-Briand Pact and with the Seventh Lambeth Conference looming, a leading article on 'The curse of war' in the Church Times claimed that the current 'revolt against war' was 'essentially Christian', it applauded 'the modern realistic war fiction which destroys the false glamour too long cast around organized bloodshed' and demanded from the Church of England an unequivocal condemnation of war. ${ }^{116}$ If it found Retreat hard to stomach, viewing it as emblematic of a 'widespread desire to discredit the Christian religion and its ministers', one of its reviewers hailed Benstead's novel as 'a perfectly honest piece of work' which laid bare the 'insuperable difficulties' of the chaplain and which was 'neither an indictment of the Church nor of the Army'. ${ }^{117}$ If the Church Times proved equivocal in its defence of the Church of England's former chaplains when even the Methodist Times and the Catholic Times judged Benstead's work

112 F. H. Brabant, Neville Stuart Talbot, I879-1943: a memoir, London 1949, 73-4.

113 Barry, Period of my life, I28.

114 Crockford's (1937), I202; R. Ellis Roberts, H. R. L. Sheppard: life and letters, London I942, i 6-I8, I89, I96. Sheppard's name does not appear in either the Army Lists or The London Gazette for the war years. Canon Stuart Morris (who founded the Church of England Peace Fellowship in 1934 and who resigned his orders five years later to work full time for the PPU) also appears to have conjured a previous career as an army chaplain. Credited as having served as a chaplain to the Royal Flying Corps, Morris was in fact rejected by the chaplaingeneral after an interview in 1915 and there is no evidence that he subsequently served in the department: M. Ceadel, Pacifism in Britain, I9I4-1945: the defining of a faith, Oxford I980, I74, and Semi-detached idealists: the British peace movement and international relations, I854-1945, Oxford 2000, 316; The Times, 3 Nov. I967, I2; 8 Nov. I967, I2; Army Lists; chaplains' card index, RAChD.

${ }^{115}$ L. Smith, Pacifists in action: the experience of the Friends Ambulance Unit in the Second World War, York 1998, I5.

116 Church Times, 7 Feb. I930, I52-3. $\quad{ }^{117}$ Ibid. I4 Feb. I930, I79; I7 Jan. I930, 77. 
to be highly unfair, ${ }^{118}$ the situation was exacerbated by the fact that other sections of the Anglican press shrank from issues that could reflect badly on the clergy. For example, while the High Church Guardian newspaper (not to be confused with the Manchester Guardian) reviewed a good deal of war-related fiction and non-fiction, it studiously ignored Simon called Peter, Disenchantment, and Goodbye to all that. The circumspection of the paper was betrayed in I932, when a leading article complained with reference to the Davidson affair that 'the lengthy reporting of the unpleasant details of such a case does untold harm to the Church of England and, indeed, to the whole cause of religion' ${ }^{119}$ Such caution was by no means ill-founded in relation to the question of army chaplaincy. Besides the controversy over Retreat, in I93 I a move had been made by pacifist MPs to do away with the largely Anglican Royal Army Chaplains' Department ${ }^{120}$ altogether. Although unsuccessful, it had been accompanied by some fevered rhetoric from the Labour benches in the House of Commons, with Reginald Sorensen, a Unitarian minister, denouncing the 'diluted and perverted type of religion' that the department was alleged to represent. ${ }^{121}$

Given these constraints, it was very much left to individuals to respond as best they could to the rising tide of unjust and mendacious criticism. Whereas the chaplain-general, A. G. E. Jarvis, collected evidence for a libel suit and sought the help of the Army Council in having Benstead disciplined for defaming fellow officers and 'degrading one honoured Department of the Service', ${ }^{122}$ 'Tubby' Clayton confronted him in the public arena. As the founder of Toc H, with its vision of 'unselfish sacrifice' and 'unselfish service' that was born in the cauldron of the Western Front, ${ }^{123}$ Clayton was deeply averse to the negative tenor of contemporary war books. ${ }^{124}$ Openly hostile to All quiet on the Western Front (which he saw as part of "that turbid stream of morbid realism with which the book-stalls, the lending libraries, the press, and even the schools, are now being flooded'), ${ }^{125}$ in a sermon preached in Oxford on the tenth anniversary of the Armistice Clayton even declared that 'forgetfulness is better than bitter memories'. ${ }^{\mathbf{1 2 6}}$ Moreover, having won the Military Cross while ministering to artillery units in the Ypres Salient,

118 Press cuttings on Retreat, RAChD: Methodist Times, 6 Feb.1930; Catholic Times, 31 Jan. I930.

119 Guardian, I7 Jan. 1930, 50; 21 Oct. I932, 8I4.

120 The department was renamed the Royal Army Chaplains' Department by King George v in March I9I9 'In recognition of the splendid service rendered by the Military Chaplains during the War': Snape, Royal Army Chaplains' Department, 257. $\quad{ }^{121}$ Ibid. 275-6.

${ }^{122}$ Letters about RETREAT by Benstead, I929: A. G. E. Jarvis, undated memorandum, and counsel's note to Jarvis, I3 Mar. I930, RAChD.

${ }^{123}$ B. Baron, The doctor: the story of Fohn Stansfeld of Oxford and Bermondsey, London 1952, 205-IO.

${ }^{124}$ Gregory, The last great war, 272.

${ }^{125}$ Letters about RETREAT by Benstead, I929: P. B. Clayton, 'Nor the years condemn', i6 Jan. I930, RAChD. ${ }^{126}$ P. B. Clayton, Plain tales from Flanders, London i929, I43. 
Clayton was well placed to lead the charge against Retreat in the popular press. In addition to writing a two-part rebuttal of it for the Evening Standard, ${ }^{\mathbf{1 2 7}}$ Clayton rebuked a sympathetic reviewer in the Daily Herald and denounced the novel in the Daily Telegraph. ${ }^{\mathbf{1 2 8}}$ Indeed, somewhat perturbed by Clayton's relentless allegations of gross misrepresentation, Benstead even tried to shift the terms of the debate, retorting that distinguished chaplains such as Clayton 'did not get those decorations and honours for preaching the gospel of peace, which is the fundamental aim of the ministers of Christ'. ${ }^{129}$ In 1932 Harry Blackburne, formerly the assistant chaplain-general of First Army, also entered the lists with a memoir entitled This also happened on the Western Front, a title that crudely echoed that of Remarque's more celebrated work. However, while Remarque's novel (which was 'neither an accusation nor a confession, and least of all an adventure') told the graphic story of ' a generation of men who, even though they may have escaped its shells, were destroyed by war', Blackburne's volume was largely a distillation of wartime letters to his wife, a modest endeavour that was intended to deflect some of the 'undeserved' criticism that the Chaplains' Department had incurred since I918. ${ }^{130}$ Although once again ignored by the Guardian, Blackburne's contribution was favourably reviewed in the TLS, which conceded that

[Blackburne] is able to give his readers a clear picture of the chaplain's life and work in France. A great deal of it was necessarily and rightly the organization of comforts for the troops ... He was evidently a man of extraordinary energy and enthusiasm for his work, with a strong spiritual influence and a happy knack of smoothing out difficulties and getting his way by quiet persuasion ... though at this time of day his tone of breezy optimism sometimes appears a little odd, it was the spirit which the period and the circumstances demanded. ${ }^{131}$

In sharp contrast to the Church of England, the reputation of their wartime chaplains was not disputed by British Roman Catholics. Relatively untroubled by currents of popular anticlericalism or by the fashionable pacifism of the I920s and '3os, there were compelling political reasons for Roman Catholics to ensure that the record of their padres was not forgotten. Against the backdrop of the Anglo-Irish War of I9I9-2I, their vaunted wartime exploits served as useful tokens of Roman Catholic loyalty to the British state and more than compensated for the odd case of desertion and even sedition

127 Letters about RETREAT by Benstead, i929: P. B. Clayton, 'Retreat', i, ii, RAChD.

128 Press cuttings on Retreat, ibid: Daily Herald, 2 I Jan. I930; Daily Telegraph, 7 Feb. I93o.

129 Ibid: Cambridge Daily Newes, ig Feb. I93o.

130 E. M. Remarque, All quiet on the Western Front, London 1982, 5; H. W. Blackburne, This also happened on the Western Front, London I932, passim; H. Blackburne, Trooper to dean, Bristol I955, 75 .

131 TLS, I3 Aug. 1932, $5^{8} 3$. 
among them. ${ }^{132}$ Especially useful in this regard was the cult of the Irish Jesuit William Doyle, who had served with the I6th (Irish) Division on the Western Front before being killed on Frezenberg Ridge in August igI7. As Doyle's spiritual journals revealed, his greatest ambition had been 'to die a Jesuit Martyr', words that he wrote in his own blood while still a novice. Already inured to extreme forms of self-mortification, Doyle saw the war as 'a new opportunity to achieve holiness by service and suffering ${ }^{\mathbf{1 3 3}}$ and, while efforts to secure a posthumous VG for Doyle proved unavailing, the cause for his canonisation was vigorously pursued by Professor Alfred O'Rahilly of University College, Cork. In February ı20 O'Rahilly published an edition of Doyle's correspondence and personal papers which, by virtue of numerous reprints over subsequent years and the non-appearance of Rawlinson's wider history, helped to cast Doyle as the war's iconic Roman Catholic chaplain. ${ }^{\mathbf{1 3 4}}$ Indeed, when confronted with the grossness of Retreat, the Catholic Times had protested that Doyle's career formed a much better basis for a book. ${ }^{135}$ In practical terms, the reputation of Roman Catholic chaplains also provided some political leverage during the passage of the Roman Catholic Relief Act of 1926 ; on speaking in the House of Lords on the need to recognise bequests to religious orders as charitable trusts, Viscount Fitzalan of Derwent essayed the following argument: 'I venture to remind your Lordships that these religious orders at the time of the War gave their full share to the work of chaplains during that conflict and you have only to ask their padre comrades of the Church of England to realise that they did their work with zeal, courage and devotion.' 136

However, and as Siegfried Sassoon hinted in his I930 Memoirs of an infantry officer, where he wrote of 'an alcoholic R.C. padre' at an infantry depot in Rouen, ${ }^{\mathbf{1 3 7}}$ here again there was a sharp divergence between myth and reality. As Rawlinson's papers demonstrate, there were numerous cases of negligent, drunken and philandering priests and of chaplains who had to be sent home in disgrace (these included a priest of the diocese of Nottingham who shocked a Nonconformist colleague by 'grumbling because he had to get up for the "f....g Mass" "). ${ }^{138}$ While all of this suggests that many dioceses and religious orders seized the opportunity to bundle their more troublesome priests into the army, the hallowed image of the plebeian, Irish and pastorally adept

132 B. S. Rawlinson to J. McMullan, 23 Nov. igi8, correspondence of Dom [B. S.] Rawlinson as principal chaplain BEF, France I918-19, Rawlinson papers; The Times, 27 Oct. IgI9, I4.

133 TLS, 8 Apr. I920, 220.

134 A. O'Rahilly (ed.), Father William Doyle S.7., London i932, passim.

135 Press cuttings on Retreat, RAChD: Catholic Times, 3I Jan. I930.

136 Hansard, House of Lords parliamentary debates, io Dec. I926, I489.

137 S. Sassoon, Memoirs of an infantry officer, London i965, I I8-ig.

${ }_{138}$ Rawlinson to Keatinge, 3 Aug. I918, Rawlinson correspondence from Boer War I90o through World War One to World War Two, Rawlinson papers. 
Catholic chaplain is belied by the fact that the Irish dioceses seem to have provided as little as I4 per cent of the army's Catholic chaplains; ${ }^{\mathbf{1 3 9}}$ indeed, almost half were drawn from the religious orders across the British Isles, orders that recruited heavily from their own grammar and boarding schools (and thus from the Catholic middle and upper classes) and among whom pastoral experience was often woefully lacking. ${ }^{140}$ Finally, and as John Brennan's work among Irish archives has revealed, the popular reputation of Catholic chaplains obscured the deep national divisions that were felt among them, with English priests often being treated with open contempt by their Irish brethren. ${ }^{141}$

Nevertheless, and notwithstanding the efforts of certain critics, by the midI930s an influential discourse on Anglican and Roman Catholic army chaplains had clearly emerged from the post-war literature. This was not even qualified by the experience of the Second World War, when the same model of chaplaincy was revived in the British army and the conduct of army chaplains was applauded by Labour MPs in the House of Commons; ${ }^{142}$ indeed, from the ig6os it was greatly strengthened by the burgeoning historiography of Britain and the First World War. As a new generation of revisionist historians have emphasised, the ig6os saw an upsurge of popular interest in the First World War, this being fed by the waning of interest in the Second, a succession of fiftieth anniversaries and by the massive impact of the BBC television series The Great War (1964). ${ }^{\mathbf{1 4 3}}$ However, the antiestablishment and anti-militarist Zeitgeist of the era ensured that what was rediscovered about the First World War was not the mood of I9I4-I8 but the disillusionment and pacifism of the inter-war years. ${ }^{144}$ While this found its supreme expression in the success of Joan Littlewood's revue Oh! What a lovely war (I963), which parodied an Anglican church parade and lampooned the piety of Sir Douglas Haig, it was also reflected in the growing celebrity of the war poets (or, at least, a narrow and favoured selection of them) and in the popular historiography of the period. ${ }^{145}$ Alan Clark, for example, found a large readership for his book The donkeys (I96I), which did much to perpetuate the notion that such was the heroism of the ordinary British Tommy that he won the war despite the wretched incompetence of his commanders. ${ }^{146}$ Significantly, all of this was reflected in the growing if rather diffuse historiography of the Church of England in the First World War, with historians

139 “"War history" material', I925, ibid.

140 Graves, Goodbye to all that, 242-3, 276; 2nd edn, I58-9, I83; D. A. Bellenger, 'Religious life for men', in V. A. McClelland and M. Hodgetts (eds), From without the Flaminian Gate: 150 years of Roman Catholicism in England and Wales, I850-2000, London I999, I42-66 passim.

141 J. Brennan, 'Irish Catholic chaplains in the First World War', unpubl. MPhil. diss. Birmingham 201 I.

143 Todman, The Great War, 29-35. $\quad{ }^{144}$ Stevenson, I9I4-I9I8, 592-3.

145 Bond, The unquiet Western Front, 51-73; Todman, The Great War, I57-8.

146 Todman, The Great War, 99-Io3. 
such as John Baynes, Albert Marrin, Alan Wilkinson and Alan Haig echoing or endorsing the Gravesian line, one that was greatly reinforced and amplified by the appearance of the second edition of Goodbye to all that as a handy Penguin paperback in $1960 .{ }^{147}$ Indeed, in his highly influential study The Church of England and the First World War (1978) Wilkinson even admitted that he had privileged his literary sources above other evidence, arguing that

In this period, [God's] Word emerged more authentically from the prose and poetry of Siegfried Sassoon and Wilfred Owen than it did from, say, the sermons of Bishop Winnington-Ingram. It is often pointed out that poets like Sassoon and Owen did not necessarily represent the feelings of ordinary soldiers. Nevertheless ... In any age the artist is one who advances through the night with sensitive antennae. He is the first to feel the long coils of bramble in the forest, the trip-wire or the hidden pit covered with brush-wood. He is the seismograph, recording the shock of the distant earthquake, which will be on its way to us next. ${ }^{148}$

The first signs of a significant shift in the historiography did not emerge until I983, when Michael Moynihan published God on our side: the British padres in World War I, a collection of chaplains' letters and diaries that mainly drew on a growing but hitherto greatly neglected source, namely the Department of Documents at the Imperial War Museum. In his foreword, Moynihan remarked on how sharply his material diverged from accepted truths:

In memoirs and popular histories of the war the padre has been mostly ignored. Where mentioned at all, it has usually been in dismissive, even derogatory, terms ... The most quoted allusion to the padre's standing among troops at the front appears in Robert Graves' classic memoir, Goodbye to All That ... [However] even accepting that Graves, invalided home early in 1917 , missed the final stages of the war when Anglican padres were actively encouraged to go up the line, the picture he has implanted of them as effete camp followers, lacking in courage and 'remarkably out of touch with their troops', is scarcely borne out by the accounts that follow. ${ }^{149}$

Since then, the growth of a new, revisionist and often unwelcome historiography of the British army in the First World War has helped to raise further questions about the role and reputation of Anglican army chaplains in particular. Aided by the publication of new sources (most notably The Bickersteth diaries in $\left.{ }^{1995}\right)^{150}$ it has fallen to military historians to go beyond the literature

${ }^{147}$ J. Baynes, Morale: a study of men and courage: the Second Scottish Rifles at the battle of Neuve Chapelle, 19I5, London I967, 204-8; A. Marrin, The last crusade: the Church of England in the First World War, Durham, NG 1974, 207-8; A. Wilkinson, The Church of England and the First World War, London 1978, I I0-I I.

${ }^{148}$ Wilkinson, The Church of England and the First World War, 2-3.

149 M. Moynihan (ed.), God on our side: the British padres in World War One, London I983, I3-I4.

150 J. Bickersteth (ed.), The Bickersteth diaries, I9I4-I9I8, London 2005. 
of the inter-war period and to rescue, however unintentionally, the reputation of the Anglican chaplain from its accustomed ignominy. Hence, and despite Peter Hart's retrograde tilts at 'sanctimonious padres' and their 'warped core beliefs' in a recent book on the battle of the Somme, ${ }^{151}$ a far more nuanced appraisal of Anglican chaplaincy has been strongly apparent in recent general works on the British army in the First World War. ${ }^{152}$ However, if military historians have rediscovered the significance of chaplains in the British army of I9I4-I8 and are increasingly wary of passing partisan judgements as to their comparative worth, church historians have proved far more reluctant to abandon entrenched perspectives. For example, a I996 doctoral thesis on Anglican chaplains in the First World War clung to the view that its subjects were superfluous and maintained that 'the Army clearly did not know what to make of uniformed chaplains on active service'. ${ }^{153}$ A decade later, Robert Lee concluded a hostile study of the Anglican clergy in nineteenth-century Norfolk by invoking some decisive truths concerning the conduct of Anglican chaplains in the First World War: 'For the most part they were not to be found at the front-line - a Church of England directive [sic] forbade chaplains to go forward of brigade headquarters. ${ }^{154}$ Similarly, an enduring sense of Catholic superiority induced Tom Johnstone and James Hagerty to offer the following gloss on Graves's claims in their 1996 book The cross on the sword: Catholic chaplains in the forces:

To their everlasting glory, many Anglican chaplains chose to disobey orders and accompany their battalion into the line as the award of three Victoria Crosses testifies. This aside, Graves was reflecting a widely held regard for Catholic chaplains within the British Expeditionary Force in France and Flanders. It was no mean achievement for the priest among the soldiers in battle. ${ }^{155}$

Even Richard Schweitzer, in The cross and the trenches: religious faith and doubt among British and American Great War soldiers (2003), proved susceptible to the myth of the inherent superiority of the practical, working-class, Irish Catholic chaplain over his Anglican counterpart: 'Roman Catholic chaplains, many of whom were recruited in Ireland or were of Irish descent, were drawn almost entirely from the working classes, and therefore experienced little social awkwardness when ministering to their followers. Consequently,

151 P. Hart, The Somme, London 2005, I89, 534.

${ }^{152}$ Holmes, Tommy, 503-2I; G. Corrigan, Mud, blood and poppycock: Britain and the First World War, London 2003, 99-IO4; C. Messenger, Call-to-arms: the British army, I9I4-I8, London 2005, $45^{2-8 .}$

153 A. M. Brown, 'Army chaplains in the First World War', unpubl. PhD diss. St Andrews I996, 226.

${ }^{154} \mathrm{R}$. Lee, Rural society and the Anglican clergy, I8I5-I9I4: encountering and managing the poor, Woodbridge 2006, I9o.

155 T. Johnstone and J. Hagerty, The cross on the sword: Catholic chaplains in the forces, London I996, II3. 
Roman Catholic chaplains did not have to resort to cigarette distribution. ${ }^{156}$ Only very recently, in fact, have church historians begun to subject the evidential basis of these and similar claims to proper scrutiny in the light of contemporary evidence. ${ }^{157}$

The papers of Padre E.V. Tanner, now in the Imperial War Museum, include a copy of a key memorandum that first appeared in the summer of I9I6. Issued by the adjutant-general of the BEF, it reads

THE POSITION OF GHAPLAINS WHEN THE BATTALION IS IN ACTION. Some doubt appears to exist as to the positions which Chaplains should occupy during active operations. It is considered that, provided their presence in no way hampers the operation in progress or in contemplation, no restriction should be placed on their movements and that Chaplains should be encouraged to go where the Senior Chaplains (C. of E. and Non-C. of E.) of Divisions decide that their services can be most advantageously employed and where they can be of most use to the troops. ${ }^{158}$

Underneath, Tanner (who had won the Military Cross twice over on the Western Front) penned a poignant note: 'Compare Robert Graves "Goodbye to all That" ${ }^{159}$ However, church historians have proved reluctant to do just this, instead rehearsing a spurious and invidious discourse on the respective merits of Anglican and Roman Catholic chaplains that has now been discarded by more judicious military historians. Although patently confused and contradictory in terms of its details, this discourse gained considerable currency in inter-war Britain and attained a new lease of life in the problematic historiography of the ig6os and i97os. Nevertheless, this discourse (which, given the inherently emotive nature of its subject, must represent one of the most potent anticlerical myths of modern British history) had very little to do with the realities of British army chaplaincy between I9I4 and I9I8. Instead, it derived its claims and its currency from a potent and even toxic interaction of post-war disenchantment, popular anticlericalism, Catholic propaganda and a marked popular appetite for the more lurid type of war book. With the evidence at hand and with the ninetieth anniversary of the Armistice behind us, it is surely time to lay this myth to rest and to look more fairly and dispassionately at the thousands of Anglican chaplains who served their Church, their country and their fellow soldiers throughout the bloody months and years of the First World War.

156 R. Schweitzer, The cross and the trenches: religious faith and doubt among British and American Great War soldiers, Westport, CT 2003, I74.

157 E. Madigan, 'Hidden courage: post-war literature and Anglican army chaplains on the Western Front, I9I4-I9I8', in H. Jones and J. O'Brien (eds), Untold war: new perspectives in First World War studies, Leiden 2008, 63-94.

158 E. V. Tanner, IWM, $\mathrm{P}_{3}$ Io.

159 Ibid. 